\title{
ON THE 75TH ANNIVERSARY OF THE JOURNAL
}

\section{TO THE READERS, AUTHORS, COLLEAGUES, AND FRIENDS OF THE JOURNAL "MEASUREMENT TECHNIQUES”}

\author{
V. N. Krutikov*
}

The year 2014 marks several important anniversaries for Russian and foreign metrologists. First, it is the 180th anniversary of the birth of the great Russian scientist and metrologist Dmitrii Ivanovich Mendeleev. He understood the immense importance of the printed word for the development of metrology and of the regular publication of a central journal of metrology for the development of calibration services in this country and for raising awareness of the uniformity of measurement and improving its accuracy. A journal of this kind, The Annals of the Main Bureau of Weights and Measures (Vremennik Glavnoi Palaty Mer i Vesov), was founded in Russia by Mendeleev. In terms of its scope and purpose, it was the predecessor of today's Measurement Techniques (Izmeritel'naya Tekhnika).

The first issue of the journal Metrology and Certification (Metrologiya i Poverochnoe Delo) appeared in 1939. World War II brought publication to a halt. The journal resumed publication in 1955 under the name Measurement Techniques (Izmeritel'naya Tekhnika).

2014 is also the 75th anniversary of the publication of the first issue of Measurement Techniques and the 45th anniversary of the supplement Metrology (Metrologiya). Throughout these years, the journal has actively discussed advances in metrology and measurement techniques in this country and helped raise the cultural level of measurement here.

Today, as in the past, Measurement Techniques unifies the efforts of Russian metrologists, creators of measurement instrumentation, and professors and instructors in institutions of higher learning in support of measurement techniques in our country at a modern level. It includes articles on the latest achievements in metrology, the development of new and improved standards for the units of physical quantities, new methods and means of measurement, ways of making measurements, and the results of international work, including comparisons of standards. All aspects of metrological activity associated with the testing, certification, and calibration of measurement instrumentation are discussed. In terms of the range of scientific and technical problems that it covers, the journal is a unique publication.

The high scientific and technical level and the practical significance of the articles published in the journal ensure its popularity and recognition, not only in Russia but also in other countries, including by such authoritative international organizations as the BIPM and OIML. The journal is included in the "list of reviewed Russian journals in which the major results of doctoral and candidate's dissertations must be published" approved by the Higher Attestation Commission (VAK) of Russia and appears in the Science Citation Index (SCI) issued by the American Institute of Scientific Information (ISI). Since 1958, the journal has been translated and published in English and is distributed in more than 50 countries, thereby promoting advances in metrology from this country and aiding in the expansion of creative links and the establishment of working contacts with foreign experts.

Along with articles by staff at the leading metrological institutions of our country, experts, and scientists, in this issue we publish greetings received by the journal.

\footnotetext{
* Editor in Chief. On behalf of the editorial board and editors of the journal Measurement Techniques.
}

Translated from Izmeritel'naya Tekhnika, No. 11, p. 3, November, 2014. 